\title{
Family Relational on Girl Child Marriage Decision A Study of Communication and Conformity Orientation in Tegaldowo Village, Rembang Regency
}

\author{
Aprilia Hening Puspitasari \\ Communication Studies Program \\ Sebelas Maret University \\ Surakarta, Indonesia \\ sariandriantoro@gmail.com
}

\author{
Widodo Muktiyo \\ Communication Studies Program \\ Sebelas Maret University \\ Surakarta, Indonesia \\ muktiyo@yahoo.com
}

\begin{abstract}
The prevalence of girl child (early) marriage in Indonesia is $23 \%$, which means 1 of 5 girls aged 20-24 years have been married less than 18 years. Decisions to marry at an immature age are vulnerable to domestic problems, one of them is early divorce because they don't have enough understanding about the consequences of marriage, has no financial independence, mental and emotional maturity. This study will examine the pattern of family communication between parents and daughters in their first marriage decision making process on mate selection in Tegaldowo Village, Gunem District, Rembang Regency using Family Communication Pattern Theory. During 2015-2017 the data show that 11 girls aged 15-20 years in Tegaldowo have been married for 2-3 times which marriage duration only 1-2 years. This research used qualitative perspective-case study method. The data were obtained by indepth interview technique, observation and document analysis and then analyzed using an interactive analysis model. The results of this study indicate the low level of communication orientation but high in conformity orientation on mate selection of marriage decision-making. Cultural factors of society also has an important role of girl child marriage decisions.
\end{abstract}

Keywords-family communication pattern theory; child marriage; marriage decision; mate selection

\section{INTRODUCTION}

Central Bureau of Statistics and UNICEF [1, p. 7] released data on girls marriage below 18 years in Indonesia is 23\%, which means one in five married women aged 20-24 years married first before 18 years, where the prevalence of marriage more occurs in rural areas $(27.11 \%)$, compared to urban areas (17.09\%).

The case of girl child marriage in Kabupaten Rembang, Central Java, was 1.576 in 2017 and 1.251 in 2017 which one of them occurred in Gunem sub-district where 2016 was 68 cases and 2017 was 56 cases with highest percentage in Tegaldowo village, 10 cases in 2015, 15 cases in 2016 and 19 cases in 2017 with an average age at the first marriage was 1417 years.

The high number of marriages in Tegaldowo is proportional to the high divorce rate, which in 2015-2017, there are 11 from 44 girls or $25 \%$ who have married for a second or even third time with an average age of 15-20 years. Even the distance between the first and second or third marriages are only 1-2 years apart. The data show women are particularly vulnerable to divorce as a result of a first marriage decision at age $<18$ years.

Making marriage decision is an important thing as the role of family communication. The results of Xia's, Xie, Zhou study [2, p. 123] states that family member communication is the most important phase in interpersonal relationships that affirms and regulates relationships through communication patterns relating to understanding of cohesion, knowledge, experience, decision-making processes and family rules and expectations of roles.

The purpose of this study is to determine the pattern of communication or family relations, especially communication between father, mother and daughter in providing socialization and education about marriage, especially choosing and determining the potential pair seen from the orientation of communication and conformity. In the orientation of communication will analyze the internal and external factors that influence while the conformity orientation will examine the level of compliance and culture of the community to the decision of choosing a partner. Family environment that became the object of research are farmers in Tegaldowo Village, Gunem District, Rembang Regency, Central Java, Indonesia.

\section{A. Family Relational and Communication}

This research is a part of interpersonal communication level using Family Communication Pattern Theory (FCPT) by Ascan F. Koerner and Mary Anne Fitzpatrick [3] which states that the family as the main socialization agent where the acquired social knowledge is learned through a series of hierarchical cognitions. The pattern of family communication is formed by conversation orientation and conformity orientation by exploring the extent to which intimacy is intertwined, the degree of individuality and other external factors.

According to Koerner and Fitzpatrick [3], communication orientation is an effort to create communication openness of all family members to freely participate in various topics of 
conversation. Families with a strong communication orientation emphasize freedom, spontaneity and the pleasure of interacting unrestricted. Conversely, less powerful communication orientations, families seldom interact, exchange thoughts, feelings, activities and only talk about specific topics.

Communication orientation was formed by internal and external aspects [4]. Internal aspects of family communication consist of : what things are often discussed, how to deliver, knowledge, experience and habits about early marriage and the selection of a spouse which includes the potential time to communicate. All of them indicate how the pattern of family communication formed in determining marriage decisions. While external aspects in family communication include: environmental aspects, where and with whom every family member interact. This external aspect will determine the knowledge possessed, the imitated habits and resources access to obtain information about potential partners.

While conformity orientation shows the level of compliance in equalizing actions, values and beliefs. Strong conformity orientation is reflected through interaction that emphasizes uniformity of beliefs and actions, focuses on harmony, avoids conflict and gives less freedom of speech, purely obedient to parents. Conversely, families with less formidable conformity are shaped by interactions that emphasize the diversity of behaviors and beliefs.

Conformity is influenced by the internal values of family and cultural values of the community adopted. According to Reiss [5], the belief system of the family serves to provide the foundation of a belief that governs interpersonal relationships. This system contains values about how members should relate to each other. The value system in family relationships organizes and gives meaning to experience, guides the choices and decisions of complex information (internal and external to the family) and plays an important role in organizing and maintaining relationships among its members.

According to [6], early interaction patterns between parent and adolescent based on the basic rules, habits are arranged so that parents need to share the values of parenting in the family. Family consisting of nucleus family and extended family communicate each other through kinship relationship so that there is habit formation and socialization of value as well as general norm or that is specific to all family member. The process of moral internalization, social and cultural norms of the surrounding community (super ego) in the family is formed through guidance from an early age so that each family member is able to make judgments about things that are considered bad by parents and society [7, pp. 24-25].

Koerner dan Fitzpark [3] devide four types of family according to the pattern of communication and conformity orientation: (1) consensual, (2) pluralistic, (3) protective and (4) laissez-faire. Families with consensual types often have conversations but have high conformity. Pluralistic families often talk about various topics but low compliance where family members have an opportunity to speak openly, yet everyone makes their own decisions. Protective family types rarely engage in conversation but adhere to the decisions of either party while the laissez-faire family rarely communicates and does not care about each other's family members.

\section{B. Marriage Decision on Mate Selection}

According to Moorhead and Griffin [8, p. 203] decision making is the determination of choice from a number of alternatives that include elements of information, goals, choice of actions and values. According to Sassler and Schoen in [9, pp. 55-56], marriage decision-making is assumed as a marriage market where decision making to choose spouse and dating is like being in a free market and strongly influenced by cultural values based on individual resources : socioeconomic status, potential earning and physical attractiveness. Mate selection process occurs in three stages : (1) finding information about potential mates, (2) determining the quality of compatibility with potential pairs, and (3) interacting more with the couple to choose between shaping or rejecting a relationship. Marriage market is considered to determine the availability of a partner. If markets give more opportunities to compare potential partners (e.g : homogeneous social characteristics, unmarried status, childlessness, and good economic opportunity), more people are likely to marry; however, if the choice of a potential spouse is small, it will lead to a voter or the girls have squeeze in choosing a marriage decision. In this research will focus on the first stage of the decision to choose to seek information and select the prospective partner. Information search includes background, marital status, socio-economic conditions and so on.

\section{METHOD}

This research is descriptive qualitative using case study method with purposive sampling technique, where the individual as informant in the research is chosen with certain criterion or purpose with consideration based on the theoretical concept used, the researcher's personal curiosity, empirical characteristic and others [10, p. 107]. The main data source of this research are 8 families consist of parents and daughters which married less than 18 years in 2014-2017. Data collection techniques were conducted through in depth interviews, observation and document analysis. Data analysis used interactive analysis model by Miles and Huberman consisting of data collection, data reduction, data presentation and conclusion or verification [11, p. 246]. The technique of examining the data use source triangulation by comparing the results of one informant interview with other informants to obtain information matching and conducting member checking to strengthen the accuracy of the research results.

\section{FINDING AND DISCUSSION}

\section{A. Family Relational and Communication}

The object of this study was farmer families in Tegaldowo Village, Rembang District, Central Java. It's commonly found girls who married under the age of 18 years. The married children generally live with the nuclear family. Some of them live together or adjacent to the extended family. The daily activities of the farmer's family are to cultivate the paddy 
fields and moor, search for fodder and sell the crops done by the husband while the wife is in charge of taking care of the house, providing the needs of family members, and doing other domestic activities. Communication between family members is done during the afternoon and evening while watching television. On Monday and Thursday farmers don't work to the fields because it is a market day. Thus Mom spends more time doing activities around the house while the father uses most of her time outside the home.

From the activities of the father and mother to the farmer's family in determining the decision of selecting and accepting a partner for the girl to be married is determined by the mother. Mother controls most of the communications associated with decision making, ranging from introducing potential partners, receiving proposal and preparing wedding events rather than dad. At a later stage this research will describe the pattern of communication and conformity orientation.

\section{B. Communication Orientation}

The findings obtained about internal factors that determine the orientation of communication in farming families are the time to meet between family members and knowledge of the risk of inadequate early marriage decision making. In timerelated internal factors, family members often use time to communicate with each other during the night. In the morning girls are more likely to interact with Mother because father since the early morning has worked on the rice fields and fields and continued to search for animal feed until noon. In the afternoons after doing housekeeping, girls have more leisure time with mothers and only occasionally with fathers. Mom has plenty of time to interact with the child.

The second internal factor that determines the pattern of family communication is the inadequate knowledge of father and mother of the farmer about the risk of marriage decisions at an early age. Knowledge of father and mother is determined, among others, by the average level of education only up to elementary school with the choice of farming type that is obtained from generation to generation and done in a traditional way. Maternal and maternal knowledge of marriage is very standard, they rarely talk about the importance of marriage for the survival of the stage of the child's life, not socializing and providing an understanding of the need for mental, physical and psychological readiness to face the consequences of new obligations in forming a new family.

Communication in determining the choice of couples greater portion performed by the mothers because of the time factor and the role it has, but obtained findings about the role of the father in determining the selection of a partner. Father is a formal determinant of obligations that must be fulfilled by the prospective partner is the application of the proposal. Only a small part of the opinion of the father who made the family decision that is father as a single parent. Father and mother have a role in determining the decision to choose a partner for girls in accordance with their respective portions.

While external factors that determine the pattern of family communication is the social environment and the role of government organizations. In social factor, the researcher concludes that the farmer's family generally has a high enough attachment with the extended family and even the neighbor or the surrounding community. Generally they choose to live in the same area and still close to their extended family. Many decisions taken by the family depend on the opinions of the extended family. For example in determining continue or not to go to school, in the management of rice fields, finances until marriage decisions. Frequency meet and interact in various activities with relatives quite often. Lack of interaction with communities outside the village area and the absence of immigrant communities makes the knowledge and access to information obtained by family members about marriage inherited very limited.

\section{Conformity Orientation}

Generally families have a strong conformity orientation, which is reflected in the high adherence of children to parental or older decisions. When parents, especially mothers already like the choice of potential mate so father just accept it. During the communication, family recognizes the involvement of extended family, especially grandparents in determining the choice of potential partners. Even parents tend to be apathetic and never ask background of prospective spouse, work or education level. It is precisely when there is a prospective male partner who asks or wants a girl to be his wife, abstinence for parents to refuse because they have a strong conformity to the understanding and social-cultural values or the stigmatization of the spinster in an 18-year-old girl single. The younger of daughter's marriage age will make the parents get greater praise from surrounding community. Parents assume refusal to refuse applications from men, even if girls do not like or know the prospective husband's parents just give an explanation that it must be lived. In this case, the fathers role in receiving proposal only from the men.

Parents don't spend much time talking and explaining to children about the consequences of early marriage decisions. The family is a protective type that rarely communicates and converts between its members [12]. The view of marriage is conventional, not too dependent and not much sharing. In some families, each member has a different opinion resulting in an argument, but quickly subsides and recovers from the household conflict. This is proved by the stay of a daughter with a husband who used to be a parent's choice. Some child and parental conflicts occur because both do not align the action. Many parents ask but give little advice. Therefore they are not expressive and do not understand the emotions of their spouse or children well.

\section{CONCLUSiOn}

Based on communication pattern, the family rarely ask the opinion of the child against the prospective partner. The decision to choose a spouse is determined by the parent (mother) without asking the opinion or consent of the children. While conformity orientation indicates high adherence to the parents. If they or other extended family have decided to accept the prospective partner then the child will obey. Family communication orientation is determined by internal and 
external factors in choosing a partner for girls. The internal factors are communication timing between family members, knowledge of children marriage risk and economic limitation. While the external factors are the social environment in which the family tends to lack interaction with people from other regions and also the lack of community organizations role (village child protection commission) in providing knowledge about the risk of children marriage, the importance of sexual education and reproductive health. It's necessary to increase the involvement of government or related institutions on the prevention efforts of child-marriage. Schools can include curriculum for sexual education and reproductive health through subjects or extra-curricular activities. The increasing of family members knowledge, will create the balanced and effective communication pattern among family members and not only tends to the conformity of parents decisions and the society cultures.

\section{REFERENCES}

[1] BPS and UNICEF, Perkawinan Usia Anak di Indonesia 2013 dan 2015 [Children Age Marriage in Indonesia], Rev. Ed. Jakarta: BPS, 2017.

[2] Y. R. Xia, X. Xie, and Z. Zhou, “Chinese adolescents' decision-making, parent-adolescent communication and relationships,” Marri. and Fam. Rev., vol. 6, no.1-2, pp. 119-145, 2004.
[3] A. F. Koerner and M. A. Fitzpatrick, "Toward a Theory of Family Communication,” J. of Commun. Theor., vol. 20, no. 1, pp. 70-91, 2002.

[4] K. M. Galvin and B. J. Brommel, Family communication: Cohesion and change. 4th ed. New York: Harper Collins, 1996.

[5] D. Reiss, The Family's Construction of Reality. Cambridge, MA: Harvard University Press, 1981.

[6] M. McGue, I. Elkins, B. Walden, and W. G. Iacono, "Perceptions of The Parent-Adolescent Relationships: A Longitudinal Investigation," Develop. Psychol., vol. 41, pp. 971-984, 2005.

[7] Riswandi, Psikologi Komunikasi [Communication Psychology]. Yogyakarta: Graha Ilmu, 2013.

[8] G. Moorhead and W. R. Griffin, Perilaku Organisasi [Organization Behavior]. Jakarta: Salemba Empat, 2010.

[9] A. L. Vangelisti, Handbook of Family Communication. New Jersey: Lawrence Erlbaum Associates, Inc., 2004.

[10] B. Bungin, Penelitian Kualitatif: Komunikasi, Ekonomi, Kebijakan Publik dan Ilmu Sosial Lainnya [Qualitative Research: Communication, Economy, Public Policy, and other Social Sciences]. Jakarta: Kencana Prenada Media Group, 2012.

[11] Sugiyono, Metode Penelitian Kualitatif, Kuantitatif, Riset dan Desain [Research Methods of Qualitative, Quantitative, Research and Design]. Bandung: Alfabeta, 2014.

[12] S. W. Littlejohn, K. Foss, and J. G. Oetzel, Theories of Human Communication. 11th ed. Illinois: Waveland Press, Inc., 2017. 